\title{
Development of Line Intersect Method for Logging Residue Assessment of Teak
}

\author{
Sarah Andini', Ahmad Budiaman ${ }^{2 *}$, Muhdin² \\ ${ }^{1}$ Graduate School of Bogor Agricultural University, Campus IPB Dramaga, Bogor, Indonesia 16680 \\ ${ }^{2}$ Department of Forest Management, Faculty of Forestry, Bogor Agricultural University, Academic Ring Road, \\ Campus IPB Dramaga, PO Box 168, Bogor, Indonesia 16680
}

Received January 11, 2017/Accepted July 4, 2017

\begin{abstract}
Line intersect method (LIM) emerged as one of the effective and efficient post-harvesting assessment methods. LIM was being widely used to estimate logging residue of plantation forest in temperate zone. This method has not been used in tropical forest plantations, including teak forests. The study was carried out to determine the best design of LIM for assessing logging residue in teak plantation. Circular and rectangular plot were used to validate the measurement of LIM's on predicting the total residual log volume. A hundred percent logging residue inventory was carried out on each plot. The LIM is modified to carried out the designs, one and combination of two and three line intersects per plot were placed on each plot. Bias, precision and accuracy criteria were calculated in order to compare the designs. The study found that the estimation of logging residue total volume using LIM was biased and tended to overestimate. LIM design with two lines combination per plot have higher precision estimation. These two designs simply involved two intersect lines laid in plot as sampling unit. However, the two intersect lines laid in the square shaped plot gave was applicable to implemented as method in assessing logging residue of teak plantation.
\end{abstract}

Keywords:design, line intersect method, logging residue, teak plantation

*Correspondenceauthor,email:abudiam@yahoo.co.id,ph.+62-251-8621244

\section{Introduction}

Forest inventory is an important activity in sustainable forest management. One of the important inventory activities is that of the logging residue. The logging residue results from a silvicultural activity, namely forest thinning and harvesting. Information about the potential residual log can be used for making decisions in forest management, such as fuel management for forest fire (van Wagner 1968), evaluate forest harvesting activity (Grushecky et al. 2007; Ghaffariyan et al. 2013), estimation of the effectiveness of forest harvesting (Budiaman \& Komalasari 2012; Matangaran \& Anggoro 2012), utilization of residual log for bioenergy (Smeets \& Faaij 2007; Viana et al. 2010; Okello et al. 2013), monitoring of forest ecosystems (Helmisaari 2011; Smolander et al. 2013), and assessment of forest ecosystem services (Sikkink \& Keane 2008; Woodall et al. 2008). As result, accurate information of logging residue inventory is needed to support sustainable forest management (Tiryana et al. 2011; Bouriaud et al. 2013).

Perum Perhutani is the only State-Owned Enterprises (SOEs) given the task to manage the state forests in the provinces of Central Java, East Java, West Java, and Banten (GoIR 2010). The majority (50.65\%) of the production forests managed by Perum Perhutani are teak plantations (Perum Perhutani 2014). Perum Perhutani applies a clear-cut silvicultural system with an artificial regeneration in the management of teak production forests. Supervision of logging and assessment after logging (post harvesting assessment) are needed to ensure forest from sustainability. In recent year, Perum Perhutani faced sustainable issue in their forest management (Tiryana 2016). Logging residue inventory is one of the activities in post-harvesting assessment and it hasnot been carried out yet by Perum Perhutani (Perum Perhutani 2008). Logging residue in Perum Perhutani commonly utilized as fuel by rural communities surrounding teak forests. Additionally, logging residue also has an important role in carbon and nutrient cycle (Woodall et al. 2008; Smolander et al. 2013). Therefore, the information about potential logging residue is important for environmental and social reason in sustainable forest management.

Inventory of logging residue can be done by a sampling method. The common sampling methods used in logging residue inventory after logging are the fixed-area sampling and the line intersect sampling (LIS). LIS is a method that was originally introduced by Warren and Olsen (1964) for time and cost efficiency in the inventory of logging residue. LIS method was developed based on the probability theory of Buffon's needle problem in 1777. At that time, LIS was described as a technique used to estimate the volume of residual log quickly on forests harvested by clear cutting. Van Wagner (1968) later developed it as a methodology used in forest fire protection and is known as the line intersect method (LIM). LIM is easier to apply on the field because the 
estimation of the residual log volume is done by measuring the log diameter (van Wagner 1968). LIM also gives unbiased results, if it is used to estimate the total volume of residual log on an area (van Wagner 1968). Currently, LIM is used to estimate not only the logging residue, but also biomass, especially necromass/coarse woody debris (Behjou \& Mollabashi 2013; Keane \& Gray 2013).

Studies on LIM to estimate logging residue has been carried out. These studies are generally conducted on pine forests in the temperate region. LIM was first used in tropical forests in 1999 in Malaysia (Forestry Department of Peninsular Malaysia 1999). In Indonesia, not many studies on LIM have been done. The estimation of the logging residue volume in the teak plantation forests in Indonesia still uses the whole tree method and fixed-area sampling (Budiaman \& Komalasari 2012; Matangaran \& Anggoro 2012; Suwarna et al. 2013; Budiaman et al.2014).

This study was aimed to develop LIM for estimating logging residue in teak forests by evaluating the performance of LIM and offer the best plot design. LIM performance is described based on three criteria, namely bias, precision, and accuracy.

\section{Methods}

Study area This study was conducted in March-April 2016 in the sub-compartment 6A of Saradan Forest Management Unit (FMU), Regional Division II of East Java, Perum Perhutani (Figure 1). The sub-compartment 6A has a density of teak stands with age class VIII (planted in 1936) of 62 trees $\mathrm{ha}^{-1}$, site quality 4 , and terrain slope of $0-10 \%$.

Definition of logging residue Logging residue in this study is defined as an unutilizied log by Perum Perhutani. This residue is the remaining log left in the logging area after skidding activity finished. The smallest diameter of the wood remains is limited to $2 \mathrm{~cm}$ (Bate et al. 2009).

Design and number of sampling plots The sample plot design in this study adopts the sub-sampling concept. Intersect lines as the units of observation in LIM were made in the plots. The plots used were in the shape of circles and squares. These shapes were selected as they are commonly used in forest inventory (Keeley \& Fotheringham 2005; Kemenhut 2007; Keane et al. 2012). The plot size used was 0.1 ha. Thus, the circle plot has a radius of $17.8 \mathrm{~m}$ and the square plot has sides of $31.6 \mathrm{~m}$.

The number of sample plots was determined according to the plot size with a sampling intensity of $12.5 \%$. The logging area of the sub-compartment $6 \mathrm{~A}$ is $10.3 \mathrm{ha}$, so the number of sample plots required is 13 plots. Sample plots were randomly placed following the logging activities on subcompartment 6A (Figure 1). The minimum distance between the plot midpoints was $37 \mathrm{~m}$ in order to avoid an overlapping between the sample plots.

There were 26 alternative designs developed in this study, namely 13 alternatives of Line Intersect Method (LIM) in circular plots and 13 alternatives of LIM in square plots. All of these 26 alternatives were developed based on the ease of making the arrangement of intersect lines that were spread in the plots. There were three main scenarios that were developed to analyze the performance of LIM in estimating the total volume of logging residue in an area. The first scenario was one intersect line with a certain length and a certain distance was used to estimate the total volume of logging residue. The second scenario was to pair intersect lines that divide the center line of the plot. The last scenario was to combine the three intersect lines. The combination of these three intersect lines was pairing the main line that divided two equally-size plots and the intersect lines from the second scenario.

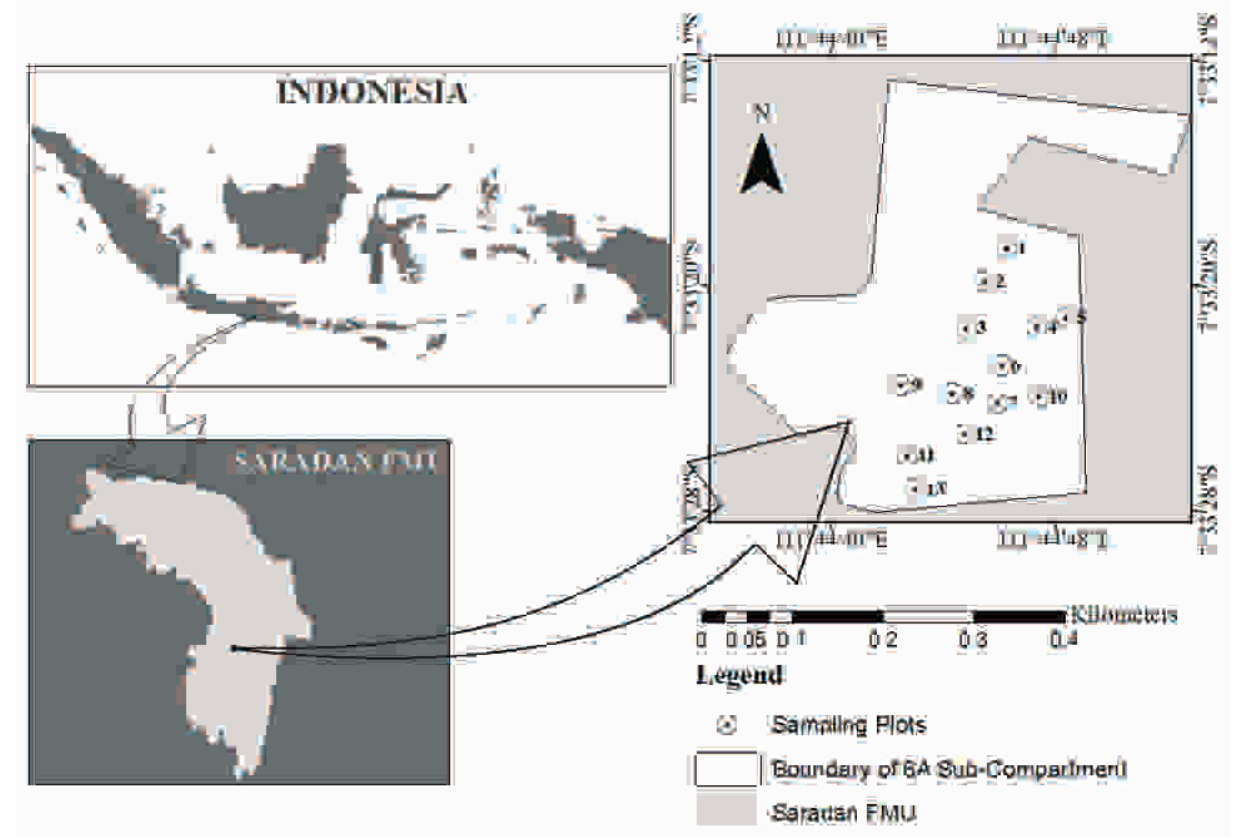

Figure 1 Location of FMU Saradan Perum Perhutani and the distribution of sampling plots. 
The intersect lines in the LIM were made in the sampling plots. The number of intersect lines as an observation unit in the LIM was made based on a certain distance. The distance was determined by dividing the center line of the plot. The division of the center line of the plot was done by considering the ease of its making in the field. One intersect line $\left(g_{1}\right)$ was placed in the middle of the center line of the plot. That intersect line divided the area of the plot into two equally-size areas. The second intersect lines were two new lines, namely $\mathrm{g}_{2}$ (left side of the plot's midpoint) and $\mathrm{g}_{2^{\prime}}$ (right side of the plot's midpoint) created by bisecting the center line of the plot which has been divided by $\mathrm{g}_{1}$. After that, four new intersect lines were created by dividing the remaining two middle lines, thus forming $\mathrm{g}_{3}, \mathrm{~g}_{3^{\prime}}, \mathrm{g}_{4}$, and $\mathrm{g}_{4}$. The illustration of the making of the intersect lines in the plot can be seen in Figure 2 and Figure 3 . The length of the intersect line in the circular plot was $\mathrm{g}_{1}=35.6 \mathrm{~m} ; \mathrm{g}_{2}=\mathrm{g}_{2^{\prime}}=30.8 \mathrm{~m} ; \mathrm{g}_{3}=\mathrm{g}_{3^{\prime}}=34.4 \mathrm{~m}$; and $\mathrm{g}_{4}=\mathrm{g}_{4}=23.6 \mathrm{~m}$. The length of the intersect lines in the square plot $\left(g_{1}, g_{2}, g_{2^{\prime}}, g_{3}, g_{3^{\prime}}, g_{4}\right.$, dan $\left.g_{4}\right)$ was the same, namely $31.6 \mathrm{~m}$. Table 1 briefly presents the length of the intersect lines and the distance between the intersect lines on each design of the LIM observed in the field.

Inventory of logging residue The inventory of logging residue was made on the circle and square plots, and intersect lines already determined. First, it was conducted on residual $\log$ on the intersect lined. Second, it was done by measuring all residual log on sample plots, the data of which were used as a validation of the estimation of the logging residue volume using the intersect lines. The data recorded in the logging residue inventory on the sample plot consists of the base-end diameter, branch diameter, and length of logging residue. Meanwhile, the recorded inventory data of logging residue on the intersect lines is the diameter of residual log located right on the intersect lines.

Estimation of logging residue volume The volume of logging residue in the plots is estimated using Brereton equation (BSN 2011). The total volume of logging residue

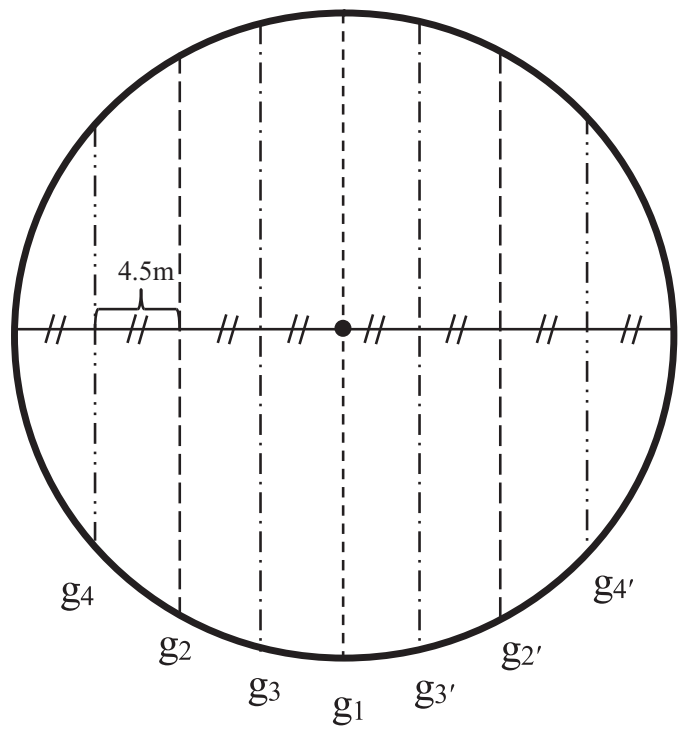

Figure 2 Line intersect arrangement in circular plot. per unit of area based on the intersected is estimated using the Equation [1] (van Wagner 1982):

$$
V=\left(\frac{k}{L}\right) \sum d^{2}
$$

Note: $V=$ volume of logging residue per unit of area $\left(\mathrm{m}^{3} \mathrm{ha}^{-1}\right)$, $k=$ constant equation (1.234), $\mathrm{d}=$ intersected diameter $(\mathrm{cm})$, and $\mathrm{L}=$ total length of intersect lines $(\mathrm{m})$.

Performance of alternative LIM design The performance of alternatives LIM designs were evaluated according to three criteria, namely bias, precision, and accuracy. Bias is the different resulted estimation against the population value (Cochran 1977). Precision is the repeatability and affinity of measurement results to their mean, while accuracy is a combination of bias and precision (van Laar \& Akça 2007).

Testing of biased estimation in each LIM design is done by making linear regression without intercept (Bate et al. 2004). The regression equation was made by comparing the volume of each measurement result on a plot ( $x$-axis) and the estimated volume of the alternative LIM design ( $y$-axis). Regression was made by making the constant $y$-intercept $\left(\mathrm{b}_{0}\right)$ of zero as shown in Equation [2].

$\mathrm{Y}_{\mathrm{i}}=\mathrm{b}_{1} \mathrm{X}_{\mathrm{i} 1}+\mathrm{e}_{\mathrm{i}}$

Note: if $b_{1}$ is worth one $(b 1=1.0)$, then this indicates that the estimated volume hasnot have a bias. Meanwhile, $b_{1}>$ 1.0 indicates that the estimated volume tends to overestimate and $\mathrm{b} 1<1.0$ tends to underestimate.

The precision of each alternative LIM design was estimated by measuring the sample variance and coefficient of variance. The greater the value of sample variance and coefficient of variance, the lower the precision of LIM design. The coefficient of variance was used to compare the variability of each volume resulting from estimation.

Accuracy testing of each LIM design was done by calculating the total mean-squared error (MSE) of the estimated volume. A bigger MSE value indicates that the

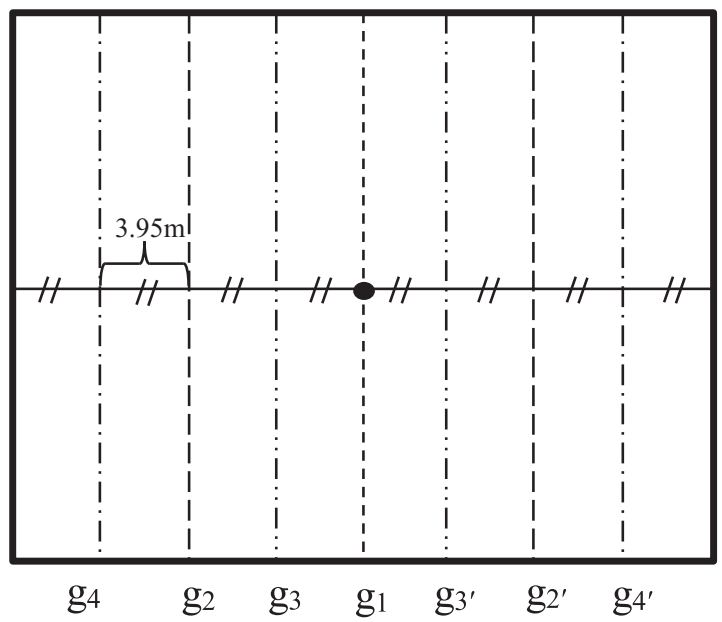

Figure 3 Line intersect arrangement in square plot. 
Table 1 Length and distance of line intersect in each alternative design of LIM

\begin{tabular}{|c|c|c|c|}
\hline Design $^{a}$ & $\begin{array}{c}\text { Intersect } \\
\text { line }\end{array}$ & $\begin{array}{l}\text { Distance of line intersect } \\
\text { from central point of plot } \\
\text { (m) }\end{array}$ & $\begin{array}{l}\text { Length of line } \\
\text { intersect (m) }\end{array}$ \\
\hline L1 & $\mathrm{g}_{1}$ & 0 & 35.6 \\
\hline L2 & $\mathrm{g}_{2}$ & 8.9 & 30.8 \\
\hline L3 & $\mathrm{g}_{2^{\prime}}$ & 8.9 & 30.8 \\
\hline L4 & $\mathrm{g}_{3}$ & 4.5 & 34.4 \\
\hline L5 & $\mathrm{g}_{3^{\prime}}$ & 4.5 & 34.4 \\
\hline L6 & $\mathrm{g}_{4}$ & 13.5 & 23.6 \\
\hline L7 & $\mathrm{g}_{4^{\prime}}$ & 13.5 & 23.6 \\
\hline L8 & $\mathrm{g}_{2}, \mathrm{~g}_{2^{\prime}}$ & 8.9 & 61.6 \\
\hline L9 & $\mathrm{g}_{3}, \mathrm{~g}_{3^{\prime}}$ & 4.5 & 68.8 \\
\hline L10 & $\mathrm{g}_{4}, \mathrm{~g}_{4^{\prime}}$ & 13.5 & 47.2 \\
\hline L11 & $\mathrm{g}_{1}, \mathrm{~g}_{2,}, \mathrm{~g}_{2^{\prime}}$ & 8.9 & 97.2 \\
\hline L12 & $\mathrm{g}_{1}, \mathrm{~g}_{3}, \mathrm{~g}_{3^{\prime}}$ & 4.5 & 104.4 \\
\hline L13 & $\mathrm{g}_{1}, \mathrm{~g}_{4}, \mathrm{~g}_{4^{\prime}}$ & 13.5 & 82.8 \\
\hline P1 & $\mathrm{g}_{1}$ & 0 & 31.6 \\
\hline P2 & $\mathrm{g}_{2}$ & 7.9 & 31.6 \\
\hline P3 & $\mathrm{g}_{2^{\prime}}$ & 7.9 & 31.6 \\
\hline P4 & $\mathrm{g}_{3}$ & 3.95 & 31.6 \\
\hline P5 & $\mathrm{g}_{3^{\prime}}$ & 3.95 & 31.6 \\
\hline P6 & $\mathrm{g}_{4}$ & 11.85 & 31.6 \\
\hline P7 & $\mathrm{g}_{4^{\prime}}$ & 11.85 & 31.6 \\
\hline P8 & $\mathrm{g}_{2}, \mathrm{~g}_{2^{\prime}}$ & 7.9 & 63.2 \\
\hline P9 & $\mathrm{g}_{3}, \mathrm{~g}_{3^{\prime}}$ & 3.95 & 63.2 \\
\hline P10 & $\mathrm{g}_{4}, \mathrm{~g}_{4^{\prime}}$ & 11.85 & 63.2 \\
\hline P11 & $\mathrm{g}_{1}, \mathrm{~g}_{2,} \mathrm{~g}_{2^{\prime}}$ & 7.9 & 94.8 \\
\hline P12 & $\mathrm{g}_{1}, \mathrm{~g}_{3}, \mathrm{~g}_{3^{\prime}}$ & 3.95 & 94.8 \\
\hline P13 & $\mathrm{g}_{1}, \mathrm{~g}_{4}, \mathrm{~g}_{4^{\prime}}$ & 11.85 & 94.8 \\
\hline
\end{tabular}

${ }^{a} \mathrm{~L}$ represents LIM design in circular plot and P represents LIM design in square plot

accuracy of the design is lower. MSE was calculated by the Equation [3] (Jordan et al. 2004):

$\mathrm{MSE}=\mathrm{s}_{\mathrm{y}}^{2}+$ bias $^{2}$

Note: $\mathrm{s}_{\mathrm{y}}^{2}=$ sample variance in the estimation of the total volume of logging residue using LIM. Bias was calculated by the following Equation [4] (Jordan et al. 2004):

$\operatorname{bias}^{2}=\mathrm{d}_{1}^{2}-\left(\mathrm{s}_{\mathrm{y}}^{2}+\mathrm{s}_{\mathrm{x}}^{2}-2 \operatorname{cov}[\mathrm{Y}, \mathrm{X}]\right)$

Note: $\mathrm{d}_{1}^{2}=$ the average squared difference of error between the estimated volume from the alternative LIM design and the actual volume; $\mathrm{s}_{\mathrm{y}}^{2}=$ sample variance of the estimated volume from the alternative LIM design and = sample variance of the actual volume; and $\operatorname{cov}[\mathrm{Y}, \mathrm{X}]$ $=$ covariance of the estimated volume from the alternative LIM design (Y) and the actual volume (X).

\section{Results and Discussion}

The volume of logging residue on various alternative LIM Different estimated volumes of logging residue are influenced by various factors, namely the number of felled trees, felling direction, and skidding direction. The number of trees felled in the plot determines the density of logging residue. The study results showed that the density of logging residue on sub-compartment $6 \mathrm{~A}$ amounted to $2.93 \mathrm{~m}^{3} \mathrm{ha}^{-1}$, with a tree-felled density of 36 trees $\mathrm{ha}^{-1}$. Besides, the direction of felling trees and skid affected the distribution of logging residue on the observation plot. Skidding was done by moving the entire teak trees to the log yard, so the log remains on the logging plots were branches and twigs of small diameters.

The diameters of the remaining teak in this study had the characteristics as presented in Figure 4. The diameters of the residual log on the circle's plot (SL), square (SP), and LIM were in the category of mostly $2-4 \mathrm{~cm}(70 \%)$. Figure 4 also shows that the larger the residual log diameter, the lower the quantity. This is caused by the whole-tree method of skidding. The entire teak trees was skidded by a tractor to log yard, so the residual log remains on the logging plots has small diameters.

The characteristics of logging residue affect the 
estimation results of the total volume of the logs as logging residue by using LIM. Figure 5 presents the estimation results of the average volume of the logging residue by using the LIM design alternatives in a circular plot (a) and square plot (b). Both figures show that the estimation of the total volume of logging residue by using LIM tends to be larger than the actual value (overestimate). However, there are alternatives whose estimation produces a value that is less than the actual value (underestimate), the L3, L5, P3, and P6.

This study produced similar findings to the study conducted by Bate et al. (2009). The result of their study showed that the estimation of the total volume of logging residue using LIM had the tendency to be overestimate. Overestimates occur to logging residue which has a diameter of $<15 \mathrm{~cm}$ and a diameter of $15-25 \mathrm{~cm}$. Meanwhile, the logging residue in this study had the characteristics of a smaller diameter when compared to the research. Nonetheless, the average deviation percentage in this study was smaller than the result of Bate et al. (2009). They reported that the overestimate percentage of the class with $15-25 \mathrm{~cm}$ diameter was $40 \%$. The percentage of overestimate in this study was $27.58 \%$ for the LIM in the circular plot and $29.43 \%$ for the LIM in the square plot. This different result occurred because there were underestimate result on the estimation of logging residue's total volume (Figure 5). Bate et al. (2009) reported that this underestimate condition tended to occur to logging residue that had a class of large diameter, i.e. $>50 \mathrm{~cm}$. Meanwhile, the largest diameter in this study was $11 \mathrm{~cm}$. The underestimate value leads lower value of the others overestimate value. Thus, the percentage of overestimate in this study was lower than reported by Bate $e t$ al. (2009).

Results of the estimation of the total volume of logging residue by using LIM with one intersect line scenario allowed underestimate to occur. It occurred in alternatives L3, L5, P3, and P6. Underestimate in this study happened due to the density of the logging residue on the four design alternatives which was lower than the other LIM design alternatives that had the same intersect line length. For example, alternatives L3 and L2 had a length of $30.8 \mathrm{~m}$, but L3 had a greater logging

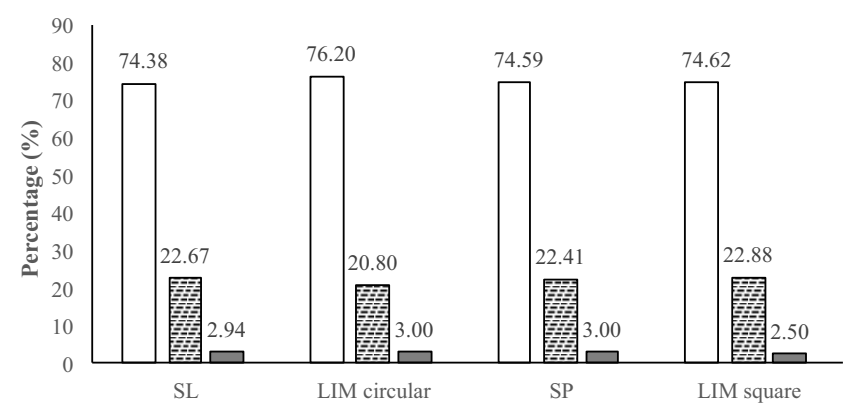

Observation unit

Figure 4 The percentage of logging residue in various observation units based on the diameter class. Diameter 2-4 ( $\square$ ), Diameter 5-7 (日), Diameter $>8$ (口). residue density so that its estimation value not underestimate (Figure 6). Meanwhile, design alternative P6, despite having an intersect line length and logging residue density equal to P7, produced a different deviation. This condition was caused by the diameter class of the logging residue in the design alternative P7 which was greater than that in P6 (Figure 6). Thus, the density and diameter of the logging residue affected the deviation on the estimating results of the total volume of the logging residue.

LIM design alternatives that had the lowest deviation value were L6 in the circular plot and P3 in the square plot. Alternative L6 had a deviation percentage with a tendency to overestimate as much as $3.95 \%$. This alternative had an intersect length of $23.6 \mathrm{~m}$ and was situated $13.5 \mathrm{~m}$ to the west of the circular plot midpoint. Design alternative L6 had a logging residue density of $0.26 \log \mathrm{m}^{-1}$ with the distribution of the logging residue diameter classes in three diameter classes (Figure 6). Meanwhile, P3 had a deviation which tended to underestimate as much as $-9.81 \%$. This design alternative had an intersect line length of $31.6 \mathrm{~m}$ and was situated $7.9 \mathrm{~m}$ to the east of the midpoint of the square plot. Design alternative P3 had a logging residue density of 0.21 $\log \mathrm{m}^{-1}$. This shows that the amount of deviation in the estimation is also influenced by the location of the intersect line design. The precise location of the intersect line is affected by the abundant condition (distribution) of the logging residue that exists in the sampling plots. In general, Figure 6 shows that the deviation of the estimation results of the total volume of logging residue by using LIM can be reduced. Adding the length of the intersect line with an appropriate intersect line arrangement design can be done to reduce the deviation of the estimation results of the total volume of logging residue.

\section{Performance of alternative LIM design \\ 1 Bias}

Deviation on the estimation of the volume of logging residue indicated a bias towards the measurement results using the LIM. Bias could be seen from the inclination value or slope $\left(b_{1}\right)$ linear regression without intercept- $y\left(\mathrm{~b}_{0}\right)$. Table 2 presents the value of the slope at various LIM design alternatives with a confidence interval of $95 \%$. The regression result indicated that the majority of LIM design alternatives had a value of $b_{1} \geq 1$. This showed that the estimation results of the total volume of the logging residue were biased with a tendency to overestimate. However, there were LIM design alternatives that had a value of $b_{1} \leq 1$. This value indicated bias on the estimation results of the total volume of the logging residue that tended to underestimate. In line with the deviation results in the total volume of logging residue, estimates for L3, L5, P3, and P6 had bias that was underestimate. Based on $b_{1}$ value, the design alternatives that had relatively low bias value were L6 (0.98) and P5 (1.11).

The bias of the estimation result of each LIM design alternative could also be seen by the magnitude of the bias $^{2}$ value in both designs (Table 3). However, the analysis of bias value elaborated in Table 3 did not show the actual magnitude of the bias produced by each LIM 

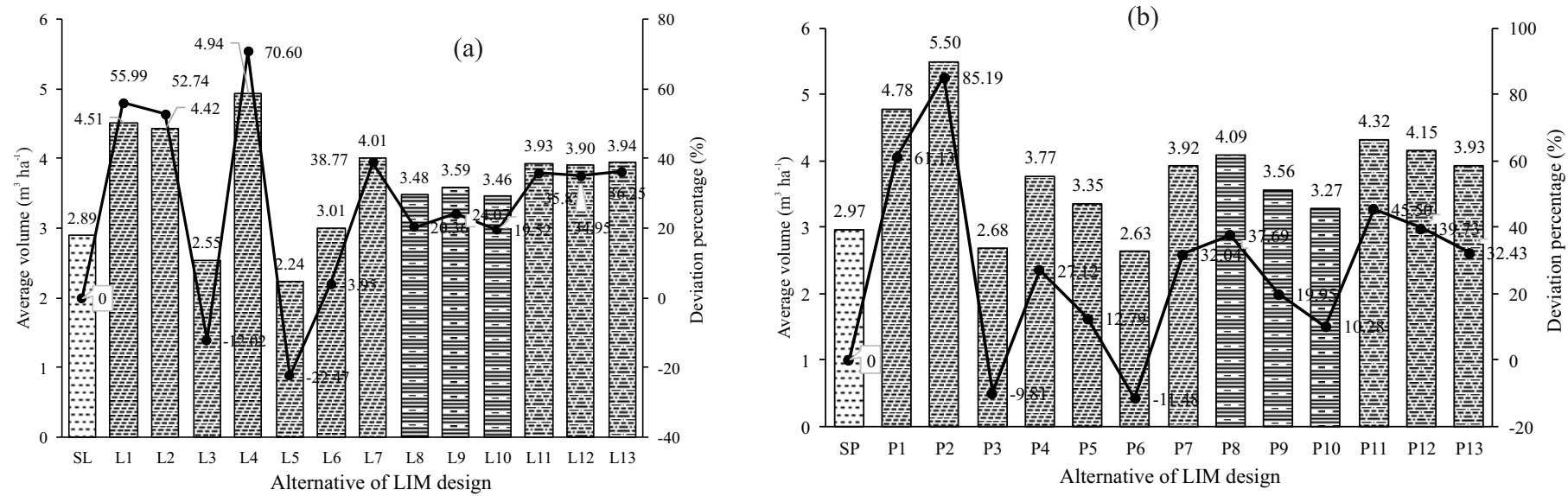

Figure 5 Average volume of logging residue in each alternative LIM design and circular (a) and square plot (b). Average volume $(\rightleftarrows)$, Deviation percentageDeviation percentage $(\rightarrow-)$.

design alternative. This was because bias ${ }^{2}$ value was considered negative. Bias in a measurement could not be avoided, but they could be reduced and corrected. The bias in the use of LIM for estimating the volume of the logging residue was caused by several things. In addition to the fact that the measured diameter was the diameter that was on the intersect line, van Wagner (1968) also mentioned the existence of underlying factors. Those factors are fulfilled assumptions that the logging residue must be cylindrical, has a horizontal position, and has a random direction or orientation.In this study, the bias had the opportunity to occur due to the non-fulfillment of two assumptions from van Wagner (1968), the horizontal position, and random orientation of the logging residue. The position of the logging residue that was not horizontal was caused by the condition of the twigs and branches which did not fully touch the ground. This was influenced by the overlapping condition of the logging residue and the shapes of the branches and twigs that were not entirely straight. Meanwhile, a uniform orientation of the logging residue occurred due to felling and skidding directions of the trees in the same observation plots. Bell et al. (1996) also proved that logging residue orientation affected the occurrence of bias in the use of LIM. This condition also resulted in log distribution in the observation plot. The distribution of logging residue affected the amount of logging residue measured as a sample. In addition, errors caused by surveyors could also be a source of bias but was not a major problem in the use of LIM (Ringvall \& Ståhl 1999). The estimation results of the total volume of the log were not horizontal and orientation were not random could be corrected. Logging residue whose log condition was not horizontal was a log that was sloping and did not fully touch the ground. Thus, the volume of the estimation result of the logging residue with this condition could be corrected through the logging residue oblique angle towards its horizontal condition. Brown (1974) described a correction factor by transforming the condition of logging residue oblique with its horizontal condition. Meanwhile, the bias due to the logging residue orientation that was not random could be reduced through intersect lines with more than one direction (Bell et al. 1996).

2 Precision

Precision is one of the components of a reliability of a method (Streiner \& Norman 2006). The precision of the estimation results of the total volume of logging residue from each LIM design alternative is seen based on sample variance (and the coefficient of variance $(\mathrm{CV})$. Both of these values are used to estimate the precision because they are sensitive to the sample size and outlier in a set of data (van Laar \& Akça 2007). Sample variance value and coefficient of variance at each LIM design alternative are presented in Figure 7. Figure 7 shows that the sample variance and $\mathrm{CV}$ of the estimation results of the volume of the logging residue are contradictory to the number of the intersect lines. The more the number of intersect lines, the less the sample variance and CV. The LIM design alternatives that used only one intersect line (L1-L7 and P1-P7) tended to have a higher variety than the designs with two (L8-L10 and P8-P10) and three (L11-L13 and P11-P13) intersect lines. This shows that as more intersect lines are used, the precision of the LIM design alternatives will be more improved. Travaglini et al. (2007) also reported the intersect length would increase the LIM' precision by reduced the sample variance value. The highest precision from the LIM alternative designs with one intersect line scheme was maintained by L3, L5, P3, and P6. The diversity value of the four designs was not much different from the diversity that was possessed by the design alternative schemes with two and three intersect line schemes. However, when viewed from the $\mathrm{CV}$ value, the scheme with three intersect lines had the highest precision compared to the other design alternative schemes. Meanwhile, L7 and P7 had the lowest precision value when compared to the other 12 design alternatives. Although L 7 had the same length of intersect line with L6 and $\mathrm{P} 7$ to $\mathrm{P} 1-\mathrm{P} 6$, the precision of $\mathrm{P} 7$ and $\mathrm{L} 7$ was very low. 

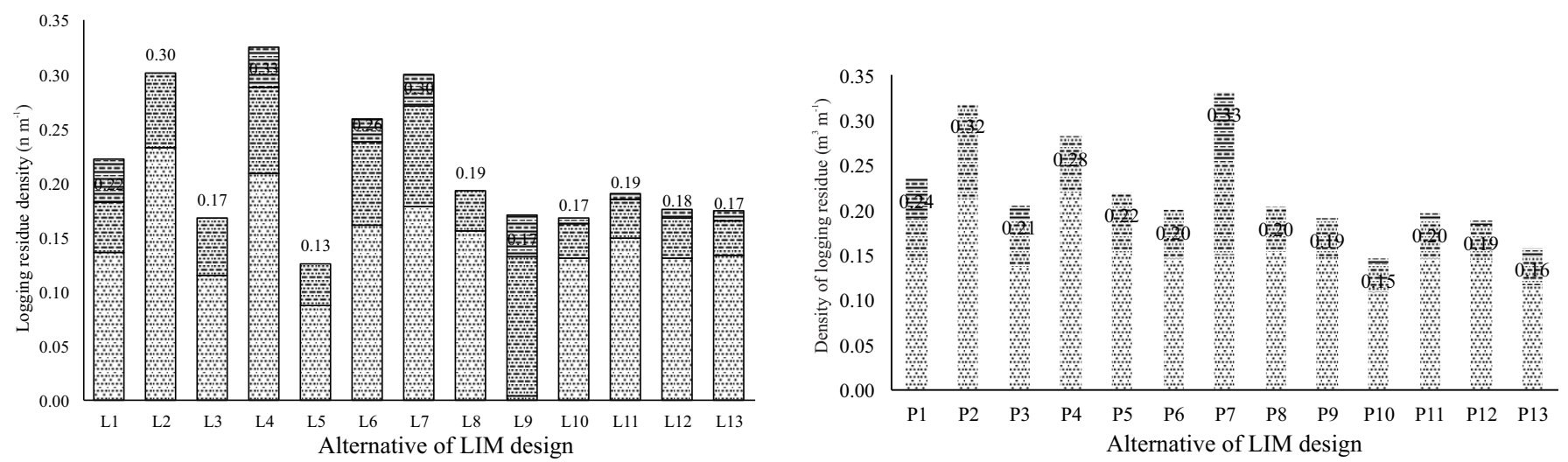

Figure 6 Density of logging residue in each line intersect of circular (a) and square (b) plot. Diameter 2-4 cm (四), Diameter 5-7 cm (घ), Diameter $>8 \mathrm{~cm}$ (日).

Table 2 Relation of estimated and actual value that showed by its slope with $95 \%$ confidence interval

\begin{tabular}{lccccc}
\hline Design & Slope $\left(\mathrm{b}_{1}\right)$ & $\begin{array}{c}\text { Confidence } \\
\text { interval } 95 \%\end{array}$ & Design & Slope $\left(\mathrm{b}_{1}\right)$ & $\begin{array}{c}\text { Confidence } \\
\text { interval } 95 \%\end{array}$ \\
\hline L1 & 1.48 & 0.64 & P1 & 1.54 & 0.64 \\
L2 & 1.62 & 0.56 & P2 & 1.86 & 0.60 \\
L3 & 0.82 & 0.65 & P3 & 0.81 & 0.68 \\
L4 & 1.62 & 0.64 & P4 & 1.25 & 0.62 \\
L5 & 0.71 & 0.66 & P5 & 1.11 & 0.62 \\
L6 & 0.98 & 0.64 & P6 & 0.83 & 0.65 \\
L7 & 1.41 & 0.62 & P7 & 1.41 & 0.61 \\
L8 & 1.22 & 0.54 & P8 & 1.33 & 0.62 \\
L9 & 1.16 & 0.67 & P9 & 1.18 & 0.58 \\
L10 & 1.18 & 0.62 & P10 & 1.12 & 0.61 \\
L11 & 1.35 & 0.56 & P12 & 1.40 & 0.64 \\
L12 & 1.27 & 0.68 & P13 & 1.39 & 0.56 \\
L13 & 1.31 & 0.63 & & 1.33 & 0.58 \\
\hline
\end{tabular}

Table 3 Performance of each alternative LIM design based on their MSE value

\begin{tabular}{lrrrrrrr}
\hline Design & $\begin{array}{c}\text { Sample } \\
\text { variance }\end{array}$ & Bias $^{2}$ & Total MSE & Design & $\begin{array}{c}\text { Sample } \\
\text { variance }\end{array}$ & Bias $^{2}$ & Total MSE $^{\text {L }}$ \\
\hline L1 & 17.04 & 1.30 & 18.35 & P1 & 22.28 & 1.59 & 23.87 \\
L2 & 22.51 & 0.85 & 23.35 & P2 & 26.66 & 4.50 & 31.16 \\
L3 & 7.15 & $0.00^{\mathrm{a}}$ & 7.15 & P3 & 6.33 & $0.00^{\mathrm{a}}$ & 6.33 \\
L4 & 25.91 & 2.18 & 28.08 & P4 & 15.24 & $0.00^{\mathrm{a}}$ & 15.24 \\
L5 & 5.65 & 77.18 & 82.83 & P5 & 13.76 & $0.00^{\mathrm{a}}$ & 13.76 \\
L6 & 20.19 & $0.00^{\mathrm{a}}$ & 20.19 & P6 & 6.43 & $0.00^{\mathrm{a}}$ & 6.43 \\
L7 & 50.48 & $0.00^{\mathrm{a}}$ & 50.48 & P7 & 60.27 & $0.00^{\mathrm{a}}$ & 60.27 \\
L8 & 5.49 & 0.03 & 5.52 & P8 & 5.16 & 0.88 & 6.04 \\
L9 & 4.92 & 0.07 & 4.99 & P9 & 3.34 & 0.14 & 3.48 \\
L10 & 15.88 & $0.00^{\mathrm{a}}$ & 15.88 & P10 & 16.60 & $0.00^{\mathrm{a}}$ & 16.60 \\
L11 & 4.96 & 0.77 & 5.74 & P11 & 3.35 & 1.59 & 4.94 \\
L12 & 4.67 & 0.64 & 5.31 & P12 & 4.55 & 1.12 & 5.66 \\
L13 & 7.48 & 0.55 & 8.02 & P13 & 10.34 & 0.23 & 10.57 \\
\hline
\end{tabular}



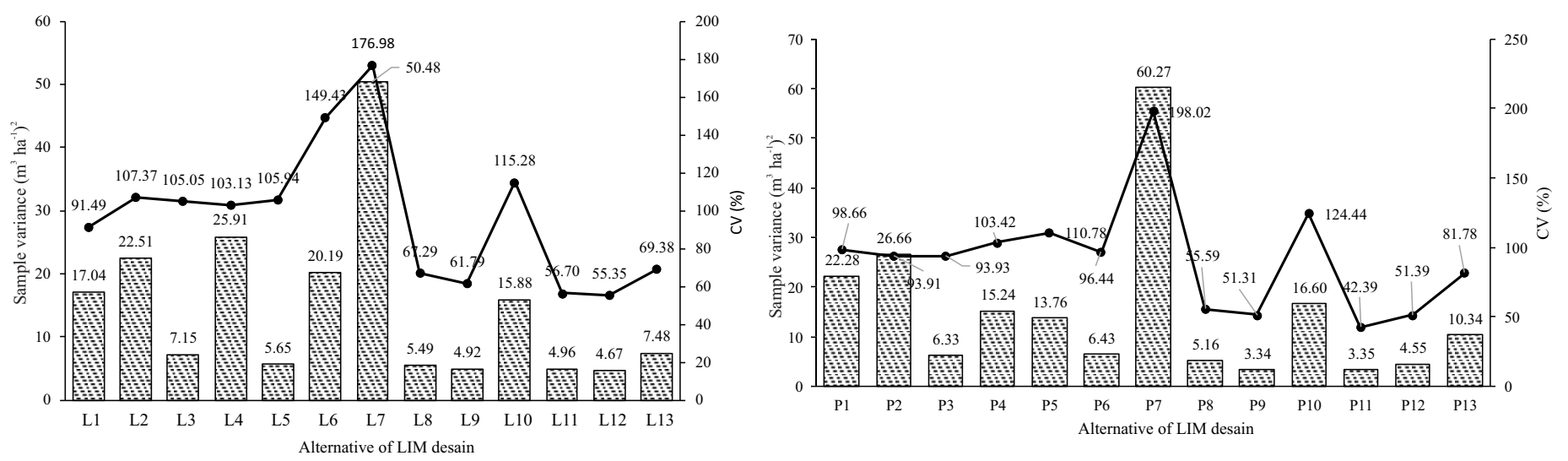

Figure 7 Sample variance and coefficient of variance value from each alternative LIM design in circular (a) and square plot (b). Sample variance (E:: $), C V(\multimap)$.

This was caused by a lack of representation of the condition of the logging residue that used both design alternatives. Thus, in addition to the number of intersect lines, the position of the intersect line also affected the precision of LIM design alternatives in predicting the volume of the logging residue. It also accommodates the logging residue distribution that may not justify. Travaglini et al. (2007) reported that LIM' precision in predicting the total volume of logging residue was influenced by $\log$ distribution.LIM design alternatives that had high precision in predicting the total volume of logging residue in this study were L12 and P9. Both of these alternatives had a lower sample variance value than the other design alternatives. Design alternative L12 had the longest intersect line, which was $104.4 \mathrm{~m}$, so its precision was high. However, when viewed from the sample variance value, $\mathrm{P} 9(63.2 \mathrm{~m})$ had a higher precision compared to designs that had longer intersect (P11, P12, and P13). Meanwhile, when judged from the CV value, $\mathrm{P} 11$ had a higher precision. This occurred because the CV value was a percentage of the deviation standard sample towards the average value of the total volume of logging residue, the estimation results.

\section{Accuracy}

Accuracy is a combination of bias and precision as measured by the MSE. The accuracy of the estimation results of the total volume of logging residue from each LIM design alternative in this study is presented in Table 3. Table 3 shows the highest accuracy owned by L9 and P9. The high accuracy owned by the two design alternatives is shown by their low MSE value, amounted to 4.99 and 3.48 , respectively. This condition is different with the results of bias and precision. Results of the bias analysis showed that designs L6 and P5 had the lowest bias. Meanwhile, results of the precision analysis showed that designs L12 and P9 had high precision. This difference occurred due to the difference in the analysis methods towards the presence of bias. In addition, accuracy was also determined by a combination of bias and precision values in the total MSE form. Van Laar \&
Akça (2007) stated that high accuracy in a measurement was attained if it had a combined value of zero bias and high precision. Thus, L9 and P9 had high accuracy because they had zero bias and high precision. Alternative designs L9 and P9 had high accuracy compared to the other design alternatives. Both designs were suitable if they were used to estimate the volume of logging residue within observation units in circular and square plots. Although both of these design alternatives did not have the longest intersect line, both designs were able to provide accurate measurement results. This suggested that the combination of the intersect lines in both designs was the best combination. Design L9 had a total length of $68.8 \mathrm{~m}$ of its intersect line inside a circular plot with a combination of two intersect lines $\mathrm{g}_{3}$ and $\mathrm{g}_{3}$. Meanwhile, design P9 had a total length of $63.2 \mathrm{~m}$ of its intersect line in a square plot which also had a combination of two intersect lines $g_{3}$ dan $g_{3^{\prime}}$. Intersect lines $g_{3}$ dan $g_{3^{\prime}}$ were located in design L9 $4.5 \mathrm{~m}$ to the west-east from the circular plot midpoint, whereas design L9 was $3.95 \mathrm{~m}$ to the west-east from the square plot midpoint. This condition indicated that the level of accuracy of the LIM alternatives in estimating the total volume of logging residue in an area was also affected by the arrangement of the intersect lines used. This was also supported by the results of other studies that stated that the composition of the intersect lines using LIM affected the accuracy of the measurement of the volume of logging residue (Bell et al. 1996; Woldendrop et al. 2004; Affleck et al.2005). These results indicated that the designs that could be used to estimate the volume of logging residue in a teak plantation were L9 and P9. They were valid for estimating logging residue in the teak plantation with age class VIII. The validation unit of this study was limited due to the fixed plots as a validator, not a logging area. This condition leads the implementation of these two alternatives in the field was done using intersect line while keeping the fixed plots, either the circular or square plots. Of these two alternatives, alternative P9 had higher accuracy than L9. Besides having high accuracy, this design had practicality when used to estimate the logging 
residue in the field. This was due to the simplicity of P9 in making intersect lines in a square plot. Nevertheless, these two alternatives still allowed bias in their estimation. It could be corrected using correction factor as Brown done in 1974 to correct the log orientation. It needs more empirical studies to formulate it and this study needs to develop more in the teak plantations of Indonesia.

\section{Conclusion}

LIM is potential to be developed as a method for estimating logging residue in a teak plantation. That the estimation results of the volume of the logging residue by using LIM had a tendency to overestimate. Of all the 26 design alternatives, L9 and P9 had high accuracy in estimating the total volume of logging residue at age class VIII Perum Perhutani FMU Saradan teak plantation. Both designs had appropriate length and arrangement of intersect lines to estimate the volume of logging residue in a teak plantation.

\section{References}

Affleck DLR, Gregoire TG, Valentine HT. 2005. Design unbiased estimation in line intersect sampling using segmented transects. Environmental and Ecological Statistics 12:139-154. https://doi.org/10.1007/s10651005-1038-1.

[BSN] Badan Standardisasi Nasional. 2011. Kayu Bundar Bagian 2: Pengukuran dan Tabel Isi. SNI 7533.2:2011. Jakarta: Badan Standardisasi Nasional.

Bate LJ, Torgersen TR, Wisdom MJ, Garton EO. 2004. Performance of sampling methods to estimate log characteristics for wildlife. Forest Ecology Management 199:83-102. https://doi.org/10.1016/j.foreco.2004.04. 021.

Bate LJ, Torgersen TR, Wisdom MJ, Garton EO. 2009. Biased estimation of forest log characteristics using intersect diameters. Forest Ecology Management 258:635-640. https://doi.org/10.1016/j.foreco.2009.04.042.

Behjou FK, Mollabashi OG. 2013. Assessment of coarse woody debris following selective logging in Caspian forests: implications for conservation and management. Journal of Forest Science 59 (3):117-124.

Bell G, Kerr A, McNickle D, Wollons R. 1996. Accuracy of the line intersect method of post-logging sampling under orientation bias. Forest Ecology Management 84:23-28. https://doi.org/10.1016/0378-1127(96)03773-5.

Bouriaud O, Stefan G, Flocea M. 2013. Predictive models of forest logging residues in Romanian spruce and beech forests. Biomass and Bioenergy 54:59-66. http://dx.doi.org/10.1016/j.biombioe.2013.03.022.

Brown JK. 1971. A planar intersect method for sampling fuel volume and surface area. Forest Science 17 (1):96-102.
Budiaman A, Komalasari P. 2012. Waste of felling and on-site production of teak squarewood of the community forest. Jurnal Manajemen Hutan Tropika 18 (3):164-168. https://doi.org/10.7226/jtfm.18.3.164.

Budiaman A, Muhtariana D, Irmawati NY. 2014. Kayu sisa penjarangan dan tebang habis hutan tanaman jati. Jurnal Hutan Tropis 2 (1):9-15.

Cochran WG. 1977. Sampling Techniques 3th Ed. New York: John Wiley \& Sons, Inc.

de Vries PG. 1986. Sampling Theory for Forest Inventory: A Tech-Yourself Course. Springer, Berlin. https://doi.org/10. 1007/978-3-642-71581-5.

Draper NR, Smith H. 1966. Applied Regression Analysis $2^{\text {th }}$ edition. New York: John Wiley \& Sons, Inc.

Forestry Department of Peninsular Malaysia. 1999. Quantification of Forest Residue and Small Dimension Logs. Forest Department Peninsular Malaysia, Terengganu State Government and Danish Corporation for Environment, Terengganu.

[GoRI] Government of Republic Indonesian. 2010. Peraturan Pemerintah Republik Indonesia Nomor 72 Tahun 2010 tentang Perusahaan Umum (Perum) Kehutanan Negara. Jakarta: Menteri Hukum dan Hak Asasi Manusia Republik Indonesia.

Ghaffariyan MR, Acuna M, Brown M. 2013. Analysing the effect of five operational factors on forest residue supply chain costs: A case study in Western Australia. Biomass and Bioenergy 59:486-493. http://dx.doi.org/10.1016/ j.biombioe.2013.08.029.

Grushecky ST, Wang J, McGill DW. 2007. Influence of site characteristics and costs of extraction and trucking on logging residue utilization in southern West Virginia. Forest Product Journal 57:63-67.

Helmisaari H-S, Hanssen KH, Jacobson S, Kukkola M, Luiro J, Saarsalmi A, Tamminen P, Tveite B. 2011. Logging residue removal after thinning in Nordic boreal forests: Long-term impact on tree growth. Forest Ecology Management 261:1919-1927. https://doi.org/10.1016/ j.foreco.2011.02.015.

Jordan GJ, Ducey MJ, Gove JH. 2004. Comparing lineintersect, fixed-area, and point relascope sampling for dead and downed coarse woody material in managed northen hardwood forest. Canadian Journal Forest Research 34:1766-1775. https://doi.org/10.1139/x04-051.

Keane RE, Gray K, Bacciu V. 2012. Spatial variability of wildland fuel characteristics in northern Rocky Mountain ecosystems. USDA Service, Rocky Mountain Research Station, Research Paper RMRS-RP-98.

Keane RE, Gary K. 2013. Comparing three sampling techniques for estimating fine woody down dead biomass. 
International Journal of Wildland Fire 22:1093-1107. http://dx.doi.org/10.1071/WF13038.

Keeley JE, Fotheringham CJ. 2005. Plot shape effects on plant species diversity measurements. Journal of Vegetation Science 16:249-256. https://doi.org/10.1111/j.16541103.2005.tb02362.x.

[Kemenhut] Kementrian Kehutanan. 2007. Peraturan Menteri Kehutanan Nomor 34 Tahun 2007 tentang Pedoman Inventarisasi Hutan Menyeluruh Berkala (IHMB) pada Usaha Pemanfaatan Hasil Hutan Kayu pada Hutan Produksi. Kementerian Kehutanan, Jakarta.

Matangaran JR, Anggoro R. 2012. Limbah pemanenan jati di Banyuwangi Jawa Timur. Jurnal Perennial 8(2):88-92.

Matangaran JR, Partiani T, Purnamasari DR. 2013. Faktor eksploitasi dan kuantifikasi limbah kayu dalam rangka peningkatan efisiensi pemanenan hutan alam. Jurnal Bumi Lestari 13 (2): 384-393.

Okello C, Pindozzi S, Faugno S, Boccia L. 2013. Bioenergy potential of agricultural and forest residue in Uganda. Biomass and Bioenergy. 56:515-525. http://dx.doi.org/10. 1016/j.biombioe.2013.06.003.

[Perum Perhutani] Perusahaan Umum Kehutanan Negara. 2008. Keputusan Direksi Perum Perhutani Nomor 783/Kpts/DIR/2008 tentang Pedoman Penyelenggaraan Tebang Habis Hutan Jati. Direktur Utama Perum Perhutani, Jakarta.

[Perum Perhutani] Perusahaan Umum Kehutanan Negara. 2011. Rencana Pengaturan Kelestarian Hutan Kelas Perusahaan Jati Kesatuan Pemangkuan Hutan Saradan. Perum Perhutani Unit II Jawa Timur, Madiun.

[Perum Perhutani] Perusahaan Umum Kehutanan Negara. 2014. Buku Statistik Perum Perhutani Tahun 2009-2013. Perum Perhutani, Jakarta.

Ringvall A, Ståhl G. 1999. Field aspects of line intersect sampling for assessing coarse woody debris. Forest Ecology Management 119:163-170. https://doi.org/10. 1016/S0378-1127(98)00521-0.

Sikkink PG, Keane RE. 2008. A comparison of five sampling techniques to estimate surface fuel loading in montane forests. International Journal of Wildland Fire 17:363-379. https://doi.org/10.1071/WF07003.

Smeets EMW, Faaij APC. 2007. Bioenergy potentials from forestry in $2050 \mathrm{An}$ assessment of the drivers that determine the potentials. Climatic Change 81:353-390. http://dx.doi.org/10.1007/s10584-006-9163-x.

Smolander A, Kitunen V, Kukkola M, Tamminen P. 2013. Response of soil organic layer characteristics to logging residues in three Scots pine thinning stands. Soil Biology \&
Biochemistry 66:51-59. http://dx.doi.org/10.1016/j.soil bio.2013.06.017.

Streiner DL, Norman GR. 2006. "Precision" and "accuracy": two terms that neither. Journal of Clinical Epidemiology 59: 327-330. https://doi.org/10.1016/j.jclinepi.2005. 09.005 .

Suwarna U, Matangaran JR, Morizon. 2013. Ciri limbah pemanenan kayu di hutan rawa gambut tropika. Jurnal lmu Pertanian Indonesia 18(1): 61-65.

Tiryana T, Tatsuhara S, Shiraishi N. 2011. Empirical models for estimating the stand biomass of teak plantations in Java, Indonesia. Journal of Forest Planning 16:177-188.

Tiryana T. 2016. Simulating harvest schedule for timber management and multipurpose management in teak plantation. Jurnal Manajemen Hutan Tropika 22(1):1-12. http://dx.doi.org/ 10.7226/jtfm. 2.1.1.

Travaglini D, Bottalico F, Brundu P, Chirici G, Minari E. 2007. Sampling deadwood within Bosco della Fontana. In: Canopy Analysis and Dynamics of a Floodplain Forest. Gianelle D, Travaglini D, Mason F, Minari E, Chirici G, Chemini C, editors. Verona: Cierre Grafica Editore.

van Laar A, Akça A. 2007. Forest Mensuration. Dordrecht: Springer. https://doi.org/10.1007/978-1-4020-5991-9.

van Wagner CE. 1968. The line intersect method in forest fuel sampling. Forest Science 14:20-26.

van Wagner CE. 1982. Practical of The Line Intersect Method. Chalk River: Petawawa National Forestry Institute, Canadian Forestry Service.

Viana H, Cohen WB, Lopes D, Aranha J. 2010. Assessment of forest biomass for use as energy. GIS based analysis of geographical availability and locations of wood-fires power plants in Portugal. Applied Energy 87: 2551-2560. http://dx.doi.org/10.1016/j.apenergy.2010.02.007.

Walpole RE. 1995. Pengantar Statistika Ed ke-3. Sumantri B, translator. Jakarta: PT Gramedia.

Waren WG, Olsen PF. 1964. A line intersect technique for assessing logging waste. Forest Science 10: 267-276.

Woldendrop G, Keenan RJ, Spencer RD. 2004. Analysis of sampling methods for coarse woody debris. Forest Ecology Management 198:133-148. https://doi.org/10. 1016/j.foreco.2004.03.042.

Woodall CW, Heath LS, and Smith JE. 2008. National inventories of down and dead woody material forest carbon stocks in the United States: challenges and opportunities. Forest Ecology Management 256:221-228. https://doi.org/10.1016/j.foreco.2008.04.003. 